\title{
CORRIGENDUM
}

\section{Identification of novel DNA-methylated genes that correlate with human prostate cancer and high-grade prostatic intraepithelial neoplasia}

JM Devaney, S Wang, S Funda, J Long, DJ Taghipour, R Tbaishat, P Furbert-Harris, M Ittmann and B Kwabi-Addo

Prostate Cancer and Prostatic Disease (2014) 17, 97; doi:10.1038/pcan.2013.58

Correction to: Prostate Cancer and Prostatic Diseases (2013) 16, 292-300; doi:10.1038/pcan.2013.21
Following the publication of this paper, the third author noticed her name was incorrect. Her name should appear as F Suer. 